\title{
Вопросы международных
}

\section{и межцерковных отношений на Священном Соборе Православной Российской Церкви 1917-1918 гг.}

\author{
А.И. Мраморнов \\ Некоммерческое партнёрство «Спасское дело»
}

Созыв Поместного Собора в 1917 г. после более чем двухвекового перерыва, имел, прежде всего, внутреннее значение для Православной Российской Церкви. Однако в эпоху продолжавшейся мировой войны и давно назревавших решений в сфере взаимодействия русского православия с другими православными и с инославными Собор не мог не коснуться международных и межцерковных вопросов. Впервые в истории Русской Церкви на официальный церковный форум прибыли официальные, избранные делегаты, служившие за рубежом и способные мнение зарубежной части Русской Церкви донести до «материнской», произвести взаимополезный обмен практиками и мнениями.

Кроме того, в условиях освобождения Церкви из-под опеки государства возникает возможность контактов с зарубежными религиозными организациями вести не через общественные организации и не через Министерство иностранных дел, а напрямую. Это открывает путь к созданию собственных церковных структур, которые должны были заниматься контактами с инославными, в частности с англиканами и старокатоликами, неформальный диалог с которыми насчитывал уже несколько десятилетий.

Попытки некоторых историков и создающих современный общественный дискурс публицистов выставить восстановление патриаршества не просто главным, а единственно значимым решением Собора разбиваются о приводимый в статье материал о том, как Собор конструировал будущую тактику взаимодействия Русской Церкви с инославными, её присутствия за рубежом, её миссии в нехристианских странах. Это было новое по своему посылу, прежде не произносимое слово. Собор и в вопросах международных связей (как и по многим другим сферам своей работы) опережал время. Многие вопросы на Соборе либо звучат впервые, либо абсолютно по-новому. Как поступить с зарубежными миссиями Русской Церкви (Японской, Китайской, Корейской, Урмийской, Палестинской)? Собор, в условиях начавшихся гонений на Русскую Церковь занимавшийся внутрицерковными про-

УДК 327.39

Поступила в редакцию 13.04.2019 г.

Принята к публикации 13.05.2019 г.

\footnotetext{
* В основу исследования положено выступление, сделанное автором 25 октября 2017 г. в стенах МГИМО на круглом столе, посвящённом 100-летнему юбилею Всероссийского Церковного Собора 1917-1918 гг. и восстановления патриаршества в Русской Православной Церкви.
} 
блемами, не мог их просто бросить. Как объединить русских эмигрантов за рубежом? Идея о Париже как центре такого объединения также звучит впервые на Cоборе.

Исследователи, ранее всерьёз касавшиеся таких вопросов, в основном смотрели на них через призму экуменизма (последующего участия Русской Церкви в экуменическом движении). Однако более правильно анализировать их в контексте эпохи самого Собора, ещё не знавшей экуменизма, который только зарождался.

Автор статьи делает вывод, что за тот год, пока Собор проводился, вопросы международных и межцерковных связей в его повестке дня перешли из разряда второстепенных в категорию приоритетны. Вывод позволяет на материале, имеющем отношение к международным и межцерковным отношениям, оспорить бытующую презрительную точку зрения о том, что Собор оказался малоэффективным. Не успевая исчерпать свою повестку, он, опережая время, сделал много для будущего служения Русской Церкви в современном мире.

Ключевые слова: Русская Православная Церковь, Поместный Собор, англикане, старокатолики, Тихон (Беллавин), Евдоким (Мещерский), А.В. Карташёв, И.П. Соколов, И.И. Соколов, экуменизм, христианское единство.

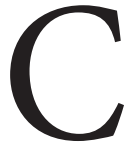

вященный Собор Православной Российской Церкви ${ }^{1}$ 1917-1918 гг. стал первым за два столетия Собором крупнейшей на тот момент в мире по численности членов Поместной Православной Церкви. Его делегаты и организаторы, заботясь преимущественно об устройстве Русской Церкви от Польши и прибалтийских земель на Западе до Японии и американских рубежей на Востоке, вовсе не исключали Собор из международного контекста, регулярно обращаясь в дискуссиях и докладах к опыту зарубежных религиозных организаций (включая православные). Но более значимыми и ощутимыми в отношении международных связей Собора были: участие в Соборе делегатов из-за рубежа, предметное обсуждение контактов русского православия с инославием, вопросы устроения миссий Русской Церкви в пределах других государств. Такого рода объединение вопросов может выглядеть несколько искусственным ввиду того, что в дореволюционный период у Церкви отсутствовало особое подразделение, ведавшее международными связями. Не было создано одного такого подразделения и на Соборе: межцерковные и межгосударственные вопросы обсуждались как в общем собрании и президиуме Собора, так и в целом ряде соборных Отделов.

В контексте развернувшейся через три десятилетия после прекращения работ Собора бурной международной деятельности русского православия изучение одного из начальных этапов этой деятельности представляется чрезвычайно актуальным. Рассмотрение перечисленных выше соборных тем позволяет исследовать международные и межцерковные связи Русской Церкви как

\footnotetext{
1 Самоназвание события, в историографии чаще называемого «Поместный Собор», «Всероссийский Церковный Собор».
} 
единую исследовательскую проблему. На первой стадии исследования мы подтверждаем, что Собор интересовали международные вопросы и заграничный опыт церковной жизни. Затем показываем, как Собор занимался этими вопросами и каков был итог этих занятий. Вопрос о дальнейшей рецепции соборных суждений и решений по международным вопросам не входит в задачи настоящего исследования.

В наличной историографии обозначенной проблематике уделено недостаточное внимание. Так, в диссертации А.В. Лепилина о соборном Отделе «О соединении инославных Церквей с Православною Церковью» сказано предельно кратко, без обращения к протоколам [9, с. 19]. Группа исследователей московской встречи православных и англикан в 1943 г. упоминала об имевшей место на Соборе 1917-1918 гг. «тенденции на продолжение отношений с англиканами», не связав результаты соборных трудов с проведением встречи [13, c. 120], хотя патриарх Сергий (Страгородский), главное действующее лицо данного исследования, активно участвовал в проведении и подготовке Собора. О создании Собором постоянного Совещания для диалога со старокатоликами и англиканами упоминает Т. Фицджеральд [16, р. 148], а о попытках Собора установить межконфессиональное сотрудничество - Д. Данн [15, р. 31]. Т.И. Шевченко изучила реакцию Собора на изменение положения православных в Финляндии после обретения страной государственного суверенитета [14].

Материалы работы соборного Отдела «О соединении церквей» специально рассмотрел лишь немецкий исследователь Г. Шульц [18], автор единственного аннотированного перевода протоколов на немецкий язык. Шульц не только проанализировал ход работы и состав Отдела, но также рассмотрел значение документов Отдела о соединении христианских церквей с точки зрения экуменизма XX в. Французский исследователь Иакинф Дестивель [3, с. 188-190] сообщает о результате трудов Отдела о соединении церквей лаконичнее. Он считает анахронизмом тезис Шульца относительно экуменической направленности итогового проекта Отдела. Дестивель называет её мотивацию «более практической, нежели богословской» [3, с. 190].

В научной литературе специально не исследована работа делегатов-иностранцев Собора (т.е. тех, кто постоянно жил и служил за пределами территории Российского государства на момент созыва Собора) и этапы их биографий, связанные с 1917-1918 гг. Эти вопросы впервые подняты в настоящей статье. Основная проблема при их изучении состоит во фрагментарности источниковой базы (дневники, записки, публикации в прессе).

Деятельность соборного Отдела «О внутренней и внешней миссии» кратко (20 страниц 600-страничной монографии) рассмотрел А.Г. Кравецкий [8]. Исследователь обратил внимание на обсуждение проблемы миссии среди соотечественников (на фоне начавшейся волны эмиграции) и поставил задачу показать, каким Отдел видел будущее русских зарубежных храмов. Эта задача в целом автором выполнена на впервые введённых в научный оборот архив- 
ных материалах. Разобран взгляд Собора на устройство Северо-Американской и Корейской миссий, на проблему русского церковного имущества на Святой Земле и создание представительств Московского Патриархата при автокефальных Церквах. По миссиям в Японии и Китае приведены лишь краткие сведения. В настоящей статье нам представляется важным продолжить обсуждение поднятых А.Г. Кравецким вопросов.

Основная исследовательская проблема, связанная с обозначенными вопросами, сводится к вопросу: занимался ли Собор 1917-1918 гг. межцерковными связями и международными вопросами всерьёз или они находились на периферии его работы? Для ответа на него проанализирована позиция делегатов, приехавших из-за пределов тогдашней России (деятельность «иностранцев»), взгляд Собора на статус и будущее зарубежных миссий Русской Церкви, усилия Собора по выстраиванию отношений с инославными. В изучаемую проблематику, кроме рецепции (о чём сказано выше), мы не включаем имевшее место обращение некоторых членов Собора к зарубежному опыту.

\section{Иностранцы на Соборе: приветствия, позиция, работа}

Собор, подготовка к которому велась в течение нескольких десятилетий, проводился в очень трудное время. Но хотя представительство Поместных Православных Церквей было заужено, в Соборе смогли принять участие представители Русской Церкви, осуществлявшие своё служение за рубежом. Согласно «Положению» о созыве Собора $(\$ 85)$, с учётом удалённости и слабой обеспеченности кадрами заграничные части Русской Церкви - Алеутско-Американская и Японская - в отличие от остальных епархий посылали на Собор по три кандидата: епископа, клирика и мирянина («внутренние» епархии по 6) [4, c. 1185]. Некоторое число делегатов имели опыт служения в зарубежных представительствах и миссиях, в т.ч. избранный патриархом святитель Тихон (Беллавин). Суждения связанных с зарубежьем делегатов могли влиять на выработку решений в Соборной палате.

В Северной Америке ${ }^{2}$ на Собор избрали священника А.Ю. Кукулевского и мирянина миссионера Ивана Пивоварника, «но они не получили своевременно пропуска от Американского правительства. С согласия части духовенства и самого избранного священника Кукулевского, явился вначале на Собор протоиерей Л.И. Туркевич, <позже> прибыл на Собор и священник А.Ю. Кукулевский... < Пивоварник> от поездки на Собор отказался» ${ }^{3}$. После дискуссии в общем собрании Собор признал протоиерея Леонида Туркевича своим полноправным членом [5, с. 247-249]. Кукулевский активно работал в заседаниях пер-

\footnotetext{
2 В состав епархии входила территория Северо-Американских соединённых штатов и Канады.

3 Архиепископ Евдоким (Мещерский) сообщал в письме на имя председателя Собора о том, что избран был от мирян Василий Журавлёв, отказавшийся от звания соборного делегата. См.: Государственный архив Российской Федерации (далее - ГАРФ). Ф. 3431. Оп. 1. Д. 472. Л. 349-350.
} 
вой сессии Собора, во вторую сессию посетил несколько заседаний в феврале 1918 г. (всего посетил 38 общих собраний). То же можно сказать о Туркевиче (посетил 53 пленарных заседания) ${ }^{4}$.

Делегацию от Северо-Американской епархии Русской Церкви возглавлял по должности архиепископ Алеутский Евдоким (Мещерский) ${ }^{5}$. Источники свидетельствуют, что он был одной из ключевых фигур по выработке Собором принципов и проектов внешних связей Русской Церкви (последующее председательство в «обновленческом» Синоде не умаляет его активности по развитию международных связей Русской Церкви в рассматриваемый нами период ${ }^{6}$ ). В своём приветствии он обратился к Собору в высокопарном слоге: «Примите приветствие от человека, который пришёл с того света и приносит сыновний привет от лица страдальцев, обагренных кровью, - миссионеров Американской Церкви. Труды их беспримерно велики. Я не преувеличу, если скажу, что никто из сидящих здесь не имеет представления о той великой работе, какую совершают обездоленные, забытые наши труженики - американские миссионеры... Число верующих с каждым годом увеличивается, в Канаде открыто более 120 самостоятельных приходов, в Центральной Америке приходы в 5-6 тысяч целиком переходят в лоно Православной Церкви. Ныне мы уже считаем около 700 приходов в Америке. И из кого только н<и> состоит Американская Православная Церковь! Она воистину Вселенская Церковь: в нее входят и галичане, и сербы, и далматы, и черногорцы, и арабы, и греки, и японцы... Посылая меня сюда, миссия просит через меня, чтобы Собор привёл Православную Церковь к такому устройству, какое она должна иметь по слову Божию и церковным канонам. Если это будет сделано, наша борьба там, за морем, будет облегчена, и мы с большим успехом будем напрягать свои силы к распространению православия в Америке. Ещё славнее станет жизнь Русской Церкви за морем. Ещё с большим рвением будут устремляться к нашей церковной ограде не только наши зарубежные братья, отторгнутые унией от лона православия, но и епископалы - это наши лучшие друзья в Америке» $[5$, c. 56]. Также из Америки Собор приветствовала Сиро-арабская миссия в лице епископа Бруклинского Евфимия (Офейш-Абдулы) [5, с. 88].

Высказываясь в пользу восстановления патриаршества, протоиерей Леонид Туркевич указывал на обстоятельство, неочевидное для служителей «внутренних» епархий: «Во всех указателях и календарях в Америке помещались заметки, что во главе Русской Церкви стоит император. Миссионеры постоянно должны были бороться с этим представлением. Сколько бы ни доказывали миссионеры, что Главой Русской Церкви является Господь Иисус Христос, а видимо управля-

\footnotetext{
4 Здесь и далее сведения о посещении соборных заседаний приведены по подсчётам священника Евгения Агеева, любезно предоставленным для настоящего исследования.

5 Посетил 148 заседаний в течение всех трёх сессий.

6 Архиепископ Евдоким (Мещерский) (1869-1935) с 1922 г. активный участник обновленчества, председатель «обновленческого» Синода, профессор «обновленческой» Московской богословской академии. С 1925 г. жил на покое.
} 
ет ей Синод, никакие наши замечания не приводили к результатам» [5, с. 548]. Представитель японского православия протоиерей Мии подтвердил: «[Японцы] указывали на то, что Пётр Великий, по своей самодержавной власти, отменил патриаршество и учредил Святейший Синод, который он и сделал своим орудием и т. п. Отсюда делали то заключение, что так как Японская Церковь находится в зависимости от Русской Церкви, а последняя находится в зависимости от царя, следовательно, Японская Православная Церковь признаёт русского царя главой, и члены её - изменники» [5, с. 596]. Сознавая потребность изменить порядок взаимодействия с зарубежными представительствами, Миссионерский отдел одобрил предложение американских делегатов привести в соответствие с американским менталитетом и законодательством название АмериканскоАлеутской епархии. Выступления Мии и Туркевича содействовали укреплению единства Русской Церкви как автокефальной и многонациональной.

Сложнее всего было положение в Японии: от имени епископа Сергия (Тихомирова), управлявшего православной миссией в этой стране, епархию представлял только упомянутый выше Симеон Мии․ Владыка Сергий в письме митрополиту Тихону (Беллавину) так объяснял своё неприбытие на Собор: «Я горю желанием братского общения с собратиями. Но после долгих размышлений я затруднился бы оставить сейчас вверенную мне Миссию без хозяина... Я здесь в Миссии - один-одинёшинек: дела по управлению Церковью, дела хозяйственные, проповедь Слова Божия - всё до мелочей (канцелярия, ризница, библиотека, школы) лежит на моих плечах» ${ }^{8}$. Недостаток бюджета и кадров усиливали необходимость для начальника миссии пребывать в ней неотступно. «Поручить... хозяйство японцам, лицам пред Св. Синодом и Мисс[ионерским] Обществом не ответственным, я не имею права» 9 .

На одном из пленарных заседаний из уст Мии прозвучало и слово в защиту института патриаршества от лица православных страны восходящего солнца [5, с. 595-597], в ответ на которое Собор принял и послал приветствие Японской Церкви. В нём соборяне желали Японской Церкви «твёрдо стоять в принятом исповедании и высоко нести знамя православия до того светлого дня, когда малая закваска Христова заквасит собой весь японский народ, о чем молился и мечтал и с верой во что скончался апостол Японии приснопамятный архиепископ Николай [Касаткин]» [5, с. 632].

Оба упомянутых заграничных протоиерея - Туркевич и Мии - оставили заметки о своём пребывании в России. Протоиерей Леонид в октябре 1917 г. отъезжал из Москвы в Елец для прочтения лекции о жизни американских приходов. «На чтении, - записывал он в дневнике, - присутствовали дамы, девицы,

\footnotetext{
7 На Соборе протоиерей Мии пробыл только в течение первой сессии. В декабре 1917 г. он вернулся в Токио, в 1918 г. стал главой Японской церковной миссии в Омске, Харбине и Иркутске «для содействия русско-японскому сближению». В январе 1919 г. он лично докладывал о ситуации в Сибири премьер-министру Японии. Продолжал служение Церкви до своей кончины в 1940 г.

8 ГАРФ. Ф. 3431. Оп. 1. Д. 472. Л. 351.

9 Там же. Л. 352.
} 
чиновники, отцы духовные и даже солдаты ... благодарность я получил от инспектора классов и других лиц совершенно непринуждённо... мне предложено было тут же посвятить ещё вечер следующего дня для ответа на вопросы, какие зародились у присутствовавших и какие желательно поставить мне для разрешения с точки зрения американской практики. Я согласился» ${ }^{10}$. Так Собор стал средством знакомства жителей российской глубинки с церковной жизнью за рубежом и средством коммуникации православных России с миром дальнего зарубежья.

Заметки протоиерея Мии были опубликованы ${ }^{11}$, но ещё никогда не переводились на русский язык.

Присутствие делегатов Поместных Церквей придавало Собору общеправославное значение. Докладывая о приглашениях других Православных Церквей в «Уставном» (Первом) отделе Предсоборного совета, профессор И.И. Соколов отмечал, что присутствие представителей автокефальных Церквей на Соборах Русской Церкви - давняя традиция, которая, правда, не меняет канонического статуса Собора как Поместного на более высокий. Предполагалось пригласить представителей четырёх Патриархатов - Константинопольского, Александрийского, Антиохийского и Иерусалимского «и Автокефальных Церквей: Кипрской, Элладской, Синайской, Сербской в Сербском Королевстве, Сербской в Австро-Угрии (Карловецкая митрополия), Русско-РумынскоСербской в Буковине и Далмации с Банатом, Сербско-Босно-Герцеговинской в Боснии и Герцеговине, Черногорской, Румынской в Румынии и Румынской в Австро- Угрии и Трансильвании с Банатом» [4, с. 243]. В июле 1917 г. Синод просил Министерство иностранных дел в срочном порядке доставить приглашения на Собор четырём патриархам. В формуляре пригласительной грамоты говорилось о просьбе российского Синода «подъять нелёгкий труд путешествия в нашу страну и своим присутствием укрепить нашу веру и ревность о Боге и дать нам от елея Вашей мудрости при соборном устроении дел нашей Церкви. Если невозможно будет для Вас утешить нас личным Вашим прибытием, Святейший Синод просит прислать Ваших представителей» [5, с. 207]. Из предстоятелей автокефальных Церквей на Собор не прибыл никто. Участие в заседаниях приняли только представители от двух традиционных православных канонических юрисдикций - Румынии и Сербии.

Из Поместных Церквей только Румынская прислала в Москву епископа преосвященного Гушского Никодима (Мунтяну), будущего румынского патриарха. Как сообщал товарищ министра иностранных дел А.А. Нератов министру исповеданий А. В. Карташёву, Румынский Синод решил также направить священника Циннока и чиновника канцелярии Синода Стамеско ${ }^{12}$. Подписные

\footnotetext{
10 Записная книжка протоиерея Леонида Туркевича // Library of Congress. Leontiĭ, Metropolitan of All America and Canada, Papers. Box 9. Folder 3. Book 2. Sheet 15 rev.

11 Панданэ (Закваска) // Сейкё Здихо (Православный вестник). Т. 7. № 5, март 1918; Т. 7, № 7, апрель 1918; Т. 7, № 8, апрель 1918; Т. 7, № 9, май 1918; Т. 7, № 10, май 1918; Т. 7, №11, май 1918; Т. 7, № 13, июль 1918 (на японском языке).

12 ГАРФ. Ф. 3431. Оп. 1. Д. 472 . Л. 523.
} 
листы общих собраний Собора свидетельствуют, что как минимум на заседании 6 сентября 1917 г. присутствовал протоиерей Иоанн Циннок ${ }^{13}$. Подписи Стамеско в подписных листах не выявлены. Глава делегации епископ Никодим присутствовал на заседаниях 6 и 13 сентября 1917 г. (приглашение на Собор было получено 24 августа), но в общем собрании Собора не появлялся. 13 сентября глава румынской делегации произнёс Собору приветственное слово, отмечая, что «этим возобновлением древних связей между вашею и нашею Церквами <Синод Румынской Церкви> чувствует себя утешенным и укреплённым, особенно в настоящее время, которое переживают наша Церковь и наша Родина» [5, с. 183]. Собор встретил приветствие Румынской Церкви торжественным пением многолетия её делегатам.

Королевская сербская миссия накануне Собора уведомила ${ }^{14}$, что представителем Сербской Церкви на соборных заседаниях назначен епископ Главиницкий Варнава (Росич), будущий сербский патриарх ${ }^{15} .16$ августа 1917 г. министр исповеданий А.В. Карташёв уведомлял настоятеля Сербского подворья в Москве архимандрита Михаила (Урошевича) о том, что «архиепископ Белградский Димитрий ${ }^{16} . .$. просит чрез российского поверенного в делах в Сербии о допущении [о. Михаила] на Собор в качестве его, митрополита Димитрия, представителя» ${ }^{17}$. Архимандрит Михаил ${ }^{18}$ с первых заседаний Собора работал регулярно, присутствовал на 152 пленарных заседаниях и принимал участие в трудах Отделов, в частности Отдела о соединении церквей.

Представительство остальных автокефальных Церквей осталось на бумаге. 14 июля 1917 г. российский посол в Афинах уведомил российское Министерство иностранных дел о том, что греческое внешнеполитическое ведомство намеревается направить в Москву на Собор митрополита Салоникского. В телеграмме, полученной в российском МИДе и переданной в копии в Св. Синод, имя митрополита не указано ${ }^{19}$. Видимо, речь шла о преосвященном Геннадии (Алексиадисе), но он не поехал в Москву по причине событий в самой Греции. Сведений о намерении кого-то из четырёх древних Патриархатов направить своего предстоятеля или представителя на Собор или об их прибытии не выявлено.

\footnotetext{
13 Там же. Д. 17. Л. 12.

${ }^{14}$ Там же. Д. 472. Л. 520.

${ }^{15}$ В жизнеописаниях Варнавы (Росича) упоминается об участии патриарха в Соборе [7, с. 648]. Подтверждений тому в протоколах, деяниях и подписных листах Собора не обнаружено.

16 Патриарх Сербский с 1920 г. Димитрий (Павлович, 1846-1930).

17 ГАРФ. Ф. 3431. Оп. 1. Д. 472. Л. 521.

${ }_{18}$ Архимандрит Михаил (Урошевич) (1868-1933) родился в семье сельского старосты, народного вождя в Горной Груже (Сербия). Окончил Московскую духовную академию, кандидат богословия. В 1906 г. возведён в сан игумена и назначен настоятелем Сербского подворья в Москве, в 1909 г. восстановил Славянский комитет, возведён в сан архимандрита. Организатор отправки добровольцев, вооружения, медикаментов и денег в сербскую армию во время Балканской войны в 1912 г., основатель Святосаввского братства (1917). Награждён орденами: сербским св. Саввы I, II, III, IV и V степени, черногорским кн. Даниила, греческим Христа Спасителя, российскими св. Анны и св. Владимира, Св. Гроба Господня. В 1918 г. арестован большевиками, отпущен по требованию прихожан, в январе 1919 г. покинул Россию.

19 ГАРФ. Ф. 3431. Оп. 1. Д. 472. Л. 518, 519.
} 
Собор получил приветствие от неправославной конфессии - конференции Американской епископальной церкви (оглашено в заседаниях Собора). Епископ Чикаго К.П. Андерсон (С.P. Anderson) и председатель Комитета Всемирной конференции Американской епископальной церкви Роберт Гардинер Сеси (Robert H. Gardiner Secy) послали российским соборянам свои «братские (так в переводе соборной канцелярии, в исходной телеграмме affectionate - A.M.) приветствия» ${ }^{20}$ (см. [5, с. 58]).

Г. Шульц обратил внимание, что Собор сразу положительно отнесся к факту получения приветствия от неправославной деноминации, однако ответ на него последовал лишь после интронизации патриарха Тихона - 10 декабря 1917 г. Шульц видел в тексте этого ответа «важный экуменический акцент» [18, S. 80]. Патриарх и секретарь Собора В.П. Шеин в ответном послании писали: «Святый Дух да ведёт весь христианский мир к окончательной победе Креста, Евангелия и Царства Любви над духовным мраком и ненавистью, которые ныне - как никогда ранее - пытаются ранить и разрушить драгоценное дело нашего Спасителя. Да объединятся все христиане в искренних молитвах за Русскую Церковь в её борьбе против врагов Христа и Религии ${ }^{21}$. Соборяне обещали присылать Американской епископальной церкви труды московского Собора. Книжки с соборными деяниями и постановлениями стали выходить в 1918 г. Вопрос о том, отсылались ли их экземпляры американским англиканам, пока не исследован.

После избрания патриарха, в декабре 1917 г. Собор приступил к подготовке общительных грамот в Поместные Православные Церкви: патриархам Константинопольскому, Александрийскому, Антиохийскому и Иерусалимскому, митрополитам Афинскому, Сербскому, Черногорскому, Румынскому 22 и БуковинскоДалматинскому ${ }^{23}$, архиепископам Кипрскому и Синайскому. Примерно в то же время, в конце ноября 1917 г., группа из 33 членов Собора во главе с профессором И.И. Соколовым озаботилась созданием особой соборной Комиссии «для обсуждения вопроса о порядке и способах сношений Русской Церкви с Православными Автокефальными Церквами» ${ }^{24} .2$ декабря 1917 г. Комиссия была создана, но она так и не заработала.

Текст общительных грамот правил патриарх Тихон, редактировал И.И. Соколов $^{25}$. В грамоте патриарху Константинопольскому Святейший Тихон просил «принять наше смирение [в] каноническое братское общение и молитвенное единение с Великою Христовою Константинопольскою Церковью» ${ }^{26}$. Отмечалось, что «ныне, с восстановлением всероссийского патриаршества, наступает новая пора для упрочения, расширения и возвеличения тесного, живого и жизненно-

\footnotetext{
${ }^{20}$ Там же. Д. 3. Л. 60-60 об.

${ }^{21}$ Там же. Л. 66.

22 Там же. Д. 227. Л. 165-165 об.

${ }^{23}$ Там же. Л. 200.

24 Там же. Д. 348. Л. 1.

${ }^{25}$ Там же. Д. 227. Л. 166-172.

${ }^{26}$ Там же. Л. 161.
} 
го взаимообщения Российской Церкви с первенствующею по чести - среди всех автокефальных Церквей Православного Востока - Церковию Константинопольской» ${ }^{27}$. По срокам и частично по содержанию это послание было пасхальным.

За отсутствием возможности отсылать патриаршие и соборные послания по каналам внешнеполитического ведомства, 18 апреля (1 мая) 1918 г. патриарх обратился к испанскому королевскому консулу в Москве Н.Н. Зыбину с письмом: «Пользуясь Вашим любезным согласием, препровождаю к Вам четыре известительные послания мои к Православным Восточных Патриархам - Константинопольскому, Александрийскому, Антиохийскому и Иерусалимскому - и Архиепископу Бухарестскому ${ }^{28}$ и вновь усердно прошу Вас не отказать в любезном содействии к пересылке означенных посланий по назначению» ${ }^{29}$. Грамоты на имя митрополита Сербского и митрополита Черногорского были переданы 4 (17) мая 1918 г. через члена Собора архимандрита Михаила (Урошевича) ${ }^{30}$.

Исторические обстоятельства крайне затруднили коммуникацию Собора с заграничными миссиями, другими православными церквами и иными конфессиями. Большинство иностранцев с Собора разъехались; в третью сессию работал лишь представитель сербской Церкви архимандрит Михаил (Урошевич) и глава американской епархии-миссии преосвященный Евдоким (Мещерский), по завершении Собора оставшийся в России. Вернувшись в места своего служения, «иностранцы» пытались следовать выработанным на Соборе решениям и публиковали свои записки. Судьбы и наследие эмигрировавших участников Собора в большинстве своём подтверждают высказываемый тезис.

\section{Собор о миссиях и зарубежных представительствах Церкви}

Сложные условия не помешали Собору вынести на обсуждение вопросы о последующем устройстве миссий и представительств русской Церкви за пределами Российского государства. Русская Церковь имела ряд миссий и зарубежных миссионерских организаций, в том числе в Китае, Японии, Корее, Северной Персии, на Святой Земле, а также заграничные приходы, традиционно подчинявшиеся санкт-петербургскому митрополиту.

Отдел о внутренней и внешней миссии, открывший работы 1 сентября 1917 г., на третьем заседании постановил создать подотделы. Международные вопросы были поручены шестому Подотделу о внешней и заграничной миссии $^{31}$, разделённому на два Подотдела: о внешней миссии и о заграничной ${ }^{32}$. В Подотделе о внешней миссии обсуждались вопросы о миссии в Корее и на Аляске, а также положение Православной Церкви в Финляндии.

\footnotetext{
27 Там же. Л. 163.

${ }^{28}$ Рукописная вставка в документе.

${ }^{29}$ Там же. Д. 227. Л. 199.

30 Там же. Л. 202.

31 Там же. Д. 337. Л. 7 об.

32 Там же. Л. 114-114 об. Протоколы названных подотделов в делах соборного фонда 3431 в Государственном архиве Российской Федерации не прослеживаются.
} 
Кроме того, в Отделе о внутренней и внешней миссии Собора был поднят вопрос об учреждении зарубежных представительств Московского Патриарха. Отделение Церкви от государства произошло в период работы Собора, и высшей церковной власти пришлось создавать за рубежом собственные структуры. Вопрос об этом поднял на Соборе приглашённый участник-эксперт, не состоявший членом Собора - архимандрит Ювеналий (Машковский). Об устройстве проектируемого представительства при вселенском патриархе он говорил: «В случае если бы вопрос о самостоятельном церковном представительстве при Вселенском патриархе был бы решён положительно и мы бы получили постоянную живую связь с Церковью, давшей нам духовное бытие, устройство в Константинополе русского подворья могло бы иметь место и без особой государственной ассигновки. Для этого достаточно было бы дать в управление лицу, представляющему Русскую Церковь, один из хорошо обеспеченных русских монастырей. На средства монастыря мог бы быть приобретён в Константинополе участок земли или даже готовый дом и построен благолепный храм и устроено монастырское подворье. Такое подворье могло бы быть местопребыванием представителя Русской Церкви. Наиболее желательным было бы приобретение места древнего Влахернского храма» ${ }^{33}$. Миссионерский отдел согласился с таким предложением в третью сессию Собора. Схожую программу действий Ювеналий предложил для представительств Русской Церкви в Лондоне и Риме ${ }^{34}$. По его мысли, «заграничные храмы, находящиеся вне пределов Автокефальных Церквей, могут быть подчинены патриарху» не напрямую, а через особого заграничного епископа. «Заграничные же храмы, находящиеся в пределах Автокефальных Церквей, желательно подчинить патриарху непосредственно с тем, чтобы их настоятели получили права церковного представительства и были бы патриаршими апокрисиариями при местных кириархах» ${ }^{35}$.

В результате проведённой в Миссионерском отделе Собора работы в Соборный совет 31 августа (13 сентября) 1918 г. был представлен доклад «Об учреждении представительства Патриарха Московского и всея России пред всеми восточными патриархами и главами православных Автокефальных Церквей», где отмечалась актуальность устройства представительства в Константинополе, «чрез который ежегодно проходят тысячи русских православных паломников, направляющихся во Святую Землю и Бар-Град ${ }^{36}$ и нуждающихся в помощи и руководстве» ${ }^{37}$.

На пленарном заседании Собора доклад о зарубежных представительствах не рассматривался, будучи отправлен на «разрешение высшего церковного управления» ${ }^{38}$, хотя Положение о внешней и внутренней миссии было принято

\footnotetext{
33 Там же. Л. 103 об.

${ }^{34}$ Там же. Л. 105-105 об.

35 Там же. Д. 350. Л. 1 об.

${ }^{36}$ Имеется в виду город Бари в Италии.

${ }^{37}$ Там же. Л. 12 об.; Там же. Д. 346. Л. 2 об.

38 Там же. Д. 346. Л. 3.
} 
Собором ещё во вторую сессию ${ }^{39}$. Собор уравнял в правах и жалованьях заграничных миссионеров с «внутренними» (теми, кто трудился на ниве христианского просвещения внутри страны, например, среди малых народов и на Дальнем Востоке). На заседании 13 (26) августа 1918 г. Миссионерский отдел признал «необходимым учреждение Патриаршего представительства у всех Вселенских Патриархов и глав автокефальных церквей с тем, чтобы чрез посредство этих представителей были впредь производимы сношения Российской Православной Церкви с Святейшими Патриархами Востока и главами Православных автокефальных Церквей» ${ }^{40}$.

Ввиду аннексии Кореи Японией (1910 г.) в Миссионерском отделе было одобрено слияние Корейской миссии с Японской. Возглавлять Корейскую миссию должен был епископ «Киотский» (в документах «Кеотосский»), становящийся помощником начальника Японской миссии ${ }^{41}$. Важным аспектом «Положения о Сеульской Корейской заграничной православной миссии» был пункт о том, что японцы, как захватчики, не должны проповедовать среди корейцев ${ }^{42}$ [8, с. 402]. Доклад о Корейской миссии не был рассмотрен Собором и передан на «разрешение высшего церковного управления» ${ }^{43}$. Решение о соединении миссий последовало в 1921 г. $^{44}$.

В докладе Подотдела внимание было уделено также миссии в Китае, которая, по мысли докладчиков архиепископа Евдокима и протоиерея Леонида Туркевича, должна была, подобно Японской, возглавляться архиереем, управляться «на основе принятых Поместным Собором законов» и получать ежегодное пособие от Российской Православной Церкви в размере 34300 рублей ${ }^{45}$.

Начальником миссии на Святой Земле соборяне также видели епископа. Преосвященный Анатолий (Грисюк) считал, что такой епископ должен быть представителем «Патриарха Всероссийского пред Иерусалимским, Александрийским и Антиохийским Патриархами и Архиепископом Синайским» ${ }^{46}$ Члены Отдела полагали необходимым добиться возможности совершать полное суточное богослужение в храме Гроба Господня на славянском языке. В связи с оттоком монашествующих из русских монастырей член Собора и Отдела профессор Б.А. Тураев видел русскую миссию в Иерусалиме центром монашеской учёности. В связи с занятием английскими войсками Иерусалима члены Собора выступили за то, чтобы защищать права Русской Церкви на Святой земле самостоятельно, без участия Российского государства. Как отмечает

\footnotetext{
${ }^{39}$ Священный Собор Православной Российской Церкви. Собрание определений и постановлений. М., 1918. Вып. 3. C. 45-51.

40 ГАРФ. Ф. 3431. Оп. 1. Д. 337. Л. 175.

${ }^{41}$ Там же. Л. 155.

42 Там же. Д. 355. Л. 2-2 об.

${ }^{43}$ Там же. Л. 5.

${ }^{44}$ В 2019 г. на Корейском полуострове решением Священного Синода Русской Православной Церкви была создана особая Корейская епархия.

${ }^{45}$ Там же. Д. 349. Л. 37 об.

${ }^{46}$ Там же. Д. 337. Л. 183 об.
} 
А.Г. Кравецкий, участник последнего заседания Миссионерского отдела начальник Иерусалимской миссии архимандрит Леонид (Сенцов) сообщил, «что английское правительство не препятствует тому, чтобы миссия продолжала свою деятельность» [8, с. 409]. Когда же в ноябре 1917 г. (по старому стилю) пришли сведения о взятии англичанами Иерусалима, на Соборе приняли решение о посылке приветственной телеграммы английскому королю. Был заготовлен проект обращения к британскому послу, но патриарх Тихон счел её отправку преждевременной ${ }^{47}$.

По итогам Отдел о внутренней и внешней миссии выработал проект «Положение об Иерусалимской миссии». Предполагалось, что главной задачей миссии должно стать «удовлетворение религиозных нужд православных паломников, прибывающих (очевидно, из России, хотя прямо об этом в 1-м параграфе не сказано - A.M.) во Святую Землю на поклонение её святыням». В проекте упоминались просветительские, чисто миссионерские и научные задачи миссии, закреплялась идея соборян о епископе как возглавителе миссии. Его должны были назначать Священный Синод и Святейший Патриарх. Миссию предполагалось финансировать ежегодно в размере 70 тыс. золотых рублей из общецерковных средств, а также за счёт дополнительного ежегодного всероссийского сбора $^{48} .31$ августа (13 сентября) 1918 г. доклад Отдела был отправлен Собором на «разрешение высшего церковного управления» ${ }^{49}$.

Миссионерский отдел Собора выработал также «Положение» (по форме, скорее, аналитическую записку) «относительно административного устройства и материального содержания Северо-Американской Епархии-Миссии». В документе подробно описаны недостатки существующего управления в Соединённых Штатах и Канаде: «Полное незнание в России местных законов делает совершенно невозможным приводить в исполнение и многие распоряжения Свят[ейшего] Синода»" мнению составителей во главе с архиепископом Евдокимом) потребностей американской миссии в размере 1278700 рублей в год. «Тогда как на Японскую Миссию отпускается свыше 100000 р[ублей] в год при 30 тамошних приходах, - для Америки едва набирается 70000 для её свыше 600 приходов. В то же время для деятелей Палестины и Сирии идут такие сравнительно крупные расходы, что каждый иеромонах имеет содержание свыше 1000 р[ублей] на год. Соотношение весьма прискорбное для работников в Сев[ерной] Америке, на которых, кроме работы чисто миссионерской и пастырской, лежат ещё труды по целому ряду учреждений Миссии, именно Народного Дома, Епархиальной типографии, Дух[овной] семинарии, Эмигрантского Дома, Сиротского приюта, Женского колледжа», - заключали авторы Положения ${ }^{51}$. Миссионерский отдел

\footnotetext{
${ }^{47}$ Там же. Д. 353. Л. 4-5.

${ }^{48}$ Там же. Д. 351. Л. 2-3.

${ }^{49}$ Там же. Л. 7.

${ }^{50}$ Там же. Д. 337. Л. 96.

51 Там же. Л. 99.
} 
постановил отделить Аляскинскую миссию от Американской вопреки позиции архиепископа Евдокима (Мещерского) $)^{52}$.

Таким образом, соборяне обсуждали в первую очередь проблемы основных очагов присутствия русского православия в зарубежных странах. В древних патриархатах главными проблемами были неустроенность и отсутствие сложившихся дипломатических институтов. Представители миссий в нехристианских странах пытались добиться формирования новых механизмов для поддержки этих миссий. Как и многие прочие сферы, над реформированием которых трудился Собор, данная сфера (внешняя миссия, международные связи) должна была получить устроение на новых началах: подконтрольность соборному управлению (о состоянии представительств и миссий за рубежом надлежало отчитываться перед очередным Поместным Собором), дебюрократизация (превалирование содержательной работы над перепиской и составлением отчётов), деформализация (решение многих проблем исходя из местных условий, без стандартных инструкций). Незавершённость решений объяснялась незавершённостью работ самого Собора, а отнюдь не пренебрежением к международному служению Русской Церкви.

\section{О регулировании церковной жизни православных за рубежом в приходах Русской Церкви}

Служившее за пределами России духовенство обладало солидным опытом, чтобы предлагать на Соборе рациональное устроение церковно-приходской жизни и епархиально-миссионерского управления. Хотя послереволюционная эмиграция только начиналась, Собор обратился к проблеме объединения в церковном отношении эмигрантов. Лучшим центром русского православия за рубежом архимандрит Ювеналий (Машковский) считал Париж, православную общину которого возглавил бы епископ ${ }^{53}$ (см. также [8, с. 395]). Ход послереволюционного развития русской эмиграции привёл к фактическому воплощению этой идеи. В том, что Собор не детально прописал будущее устройство миссии, можно усматривать и недостаток (не от того ли произошли юрисдикционные конфликты в эмигрантской церковной жизни?), и некую промыслительность. Из 1918 года было трудно предсказать масштабы и все очаги эмиграции, не говоря о возникновении Зарубежного Синода, института всезарубежных соборов и т.п.

Особо следует сказать о Финляндии, которая превратилась в зарубежную частью русского православия именно во время работы Собора. Ещё на рассмотрение Предсоборного совета Финляндская епархия представила проект «Уложения о Православной Церкви в Финляндии», по которому православие, оставаясь в канонической зависимости от Российской Церкви, должно было

\footnotetext{
52 Там же. Л. 117.

${ }^{53}$ Там же. Д. 350. Л. 2 об.
} 
пользоваться автономией «во внутренней... своей жизни и управлении» [4, c. 413]. Кроме того, высшей церковной власти были представлены «Положение о Церковном Соборе Православной Церкви в Финляндии» и «Правила для замещения вакантных мест членов причтов в приходах Православной Церкви Финляндии», которые формировали бы новый соборный строй управления Финляндской Церкви. Названные проекты легли в основу подготовленного соборным Миссио-нерским отделом доклада «Об устройстве Православной Церкви в Финляндии». Собор не рассматривал доклад, передав его «на распоряжение высшего церковного управления» ${ }^{54}$.

В мае 1918 г. член Собора М.Ф. Глаголев доложил о гонениях на русское население в Финляндии и предложил Церкви организовать помощь православным. По решению Соборного Совета Глаголев вместе с священником Петроградской епархии (митрополит Вениамин (Казанский) назначил члена Собора протоиерея Петра Лепорского ${ }^{55}$ ), должны были отправиться в Финляндию для ходатайства «пред подлежащими властями об ограждении русских людей в Финляндии, подвергшихся там преследованиям» ${ }^{56}$. Решено было просить о заступничестве шведского посла. В дальнейшем эти дела, как и возбуждённый финнами вопрос об автокефалии Православной Церкви в их государстве, были переданы высшему церковному управлению ${ }^{57}$ (см. также [14, с. 92]).

\section{Вопрос об отношении к инославным}

Изначально в структуре Собора не было подразделения, которое разрабатывало вопросы межцерковных отношений. Такого подразделения не было и до революции в целом у Русской Церкви, у её высшего властного органа - Святейшего Синода, несмотря на весьма углублённые контакты с инославными, которые осуществлялись в основном в формате полуофициального диалога. Российскую сторону зачастую представляли общественные организации, как в случае со старокатоликами [см. 11; 12].

Вопрос о создании особого Отдела по вопросам межцерковных контактов был поставлен в конце второй сессии Поместного Собора, в середине 1918 г. Ранее Миссионерский отдел предполагал учредить постоянное Совещание по сношению с «Епископальною Церковию и её представителями в Великобритании и Сев[ерной] Америке в целях уяснения взаимного нашего с нею отношения» ${ }^{58}$, приняв предложение 45 членов Собора во главе с архиепископом Евдокимом ${ }^{59}$. Собор постановил передать это предложение в свой Миссионерский отдел ${ }^{60}$.

\footnotetext{
54 Там же. Д. 352. Л. 16 об.

${ }_{55}$ Там же. Д. 354. Л. 10.

56 Там же. Л. 1-4.

${ }^{57}$ Там же. Л. 15-18.

58 Там же. Д. 347. Л. 1 об.

${ }^{59}$ Там же. Д. 606. Л. 2 об.

${ }^{60}$ Там же. Л. 1.
} 
Там было запрошено мнение члена Собора профессора И.П. Соколова, который предложил существовавшую прежде Комиссию по старокатолическому и англиканскому вопросам разделить на две и предоставить Патриарху право назначения их членов. На этом движение дел по заявлению 45-ти приостановилось ${ }^{61}$. Вопрос «застрял» в Миссионерском отделе, и лишь 5 (18) сентября 1918 г. предложение отдела о создании совещания было отправлено в Отдел о соединении церквей ${ }^{62}$.

19 июля (1 августа) 1918 г. заявлением об образовании соответствующего отдела выступили уже 33 соборянина, подчеркнув, что Собор работает «в таких исключительно тяжких для всей христианской церкви условиях, когда... огромная опасность со стороны неверия и безбожия угрожает не одному какому-либо христианскому исповеданию, а всему христианству» ${ }^{63}$. Выработанный материал соборяне рассчитывали использовать «в период междусоборный» ${ }^{64}$. Состав подписантов этого заявления впервые внимательно изучил Г. Шульц, который обратил внимание на то, что 12 из них были из Москвы и 9 из Петрограда [18, S. 78]. Это логично, если учесть, что до революции процесс выстраивания диалога с англиканами и старокатоликами проходил именно в столицах [см. 11, 12].

На 138-м пленарном заседании Собора 21 июля (3 августа) 1918 г. Отдел был учреждён. В него записались члены Собора (составленная нами таблица посещений заседаний Отдела его членами приводится в приложении к настоящей статье $)^{65}$.

Первое заседание Отдела прошло 11 (24) августа 1918 г. под председательством архиепископа Евдокима (Мещерского), избранного постоянным председателем Отдела. Товарищами председателя стали единоверческий епископ Охтенский Симон (Шлеёв) и профессор И.П. Соколов (после отказа профессора Казанской духовной академии В.А. Керенского, ведущего в то время эксперта Русской Церкви по диалогу с инославными христианами) ${ }^{66}$. Отдел работал в зале гимназии при московском Скорбященском монастыре и в Московском епархиальном доме, где в основном заседал Собор.

На втором заседании 13 (26) августа 1918 г. обсуждалась работа созданной в 1893 г. Комиссии по старокатолическому вопросу и контакты с англиканами. Священник Эмилиан Витошинский высказался за приглашение представителей инославных исповеданий на заседания Отдела, но члены Отдела сочли это преждевременным ${ }^{67}$. Профессор В.А. Керенский отметил препятствия в диалоге со

\footnotetext{
${ }^{61}$ Там же. Д. 494. Л. 45.

62 Также см. Д. 495. Л. 15а.

${ }^{63}$ Там же. Д. 494. Л. 1.

${ }^{64}$ Там же.

${ }^{65}$ Там же. Д. 495. Л. 1. На листе записи к красивому рукописному заголовку «Запись в Отдел о соединении Церквей» было допечатано на машинке: «христианских», причём кто-то из членов Собора - возможно, первый записавшийся архимандрит Александр (Григорьев) — начертал: «Каких Церквей?».

${ }^{66}$ Там же. Л. 2-2 об.

67 Там же. Л. 4.
} 
старокатолическим движением: «особенности» учения (черты, свойственные католицизму в целом), неразработанность православной догматики и «пренебрежительное отношение старокатолических учёных к православной богословской науке» ${ }^{68}$. Епископ Симон (Шлеёв) вину за взаимное отчуждение возлагал на «неумеренных обличителей», напоминая: «В Кирилловой книге о латинянах говорится в очень резком порицательном тоне. В наших учебниках католикам приписывается то, чему они вовсе не учат. Католиков обличают за индульгенции, а между тем и у нас иерусалимский Патриарх за деньги даёт разрешительные грамоты от всех грехов. Нужно исправить и очистить наши книги» ${ }^{69}$. Отдел решил вопрос о единении с каждым исповеданием рассматривать особо, заслушав доклады председателя об Американской епископальной церкви, профессора В.А. Керенского о старокатоличестве и профессора И.П. Соколова о католицизме ${ }^{70}$ (см. также [18, S. 87-88]).

Третье заседание Отдела началось 17 (30) августа 1918 г. с доклада архиепископа Евдокима, обратившего внимание членов Отдела на признание епископалами таинства исповеди ${ }^{71}$. В протоколе заседания отсутствует запись дискуссии, на что обратил внимание ещё Г. Шульц.

В центре четвёртого заседания 20 августа (2 сентября) оказалось выступление А.В. Карташёва о потрясении основ европейской цивилизации. «Самое яркое выражение этого потрясения мы имеем в русском большевизме. Пышно расцветши на русской почве, он, однако, вышел не из недр русского народного духа, а есть плод безрелигиозной культуры Запада. То очарование христианством, которым иногда некогда жила Европа, пало, и она ударилась в иную сторону» ${ }^{72}$. Тем не менее, церковный историк, в недавнем прошлом последний обер-прокурор Св. Синода и первый и единственный министр исповеданий Временного правительства, предложил созвать общеевропейскую конференцию для углубления сотрудничества между конфессиями ${ }^{73}$. Архиепископ Евдоким указал, что такая конференция готовилась в Америке и он испрашивал у Синода разрешения принять в ней участие, однако Синод «позволил только послать “дозорного”, иначе говоря, шпиона» (архиепископ и в дальнейшем обвинял Синод в уклонении от диалога с инославными). Владыка выступил за создание специальной комиссии Русской Церкви для участия в подобных конфессиональных и межконфессиональных конференциях. Другие члены Отдела указали, что Карташёв имел в виду иную по содержанию и составу участников конференцию, нежели американская, о которой говорил Евдоким ${ }^{74}$.

\footnotetext{
${ }^{68}$ Там же. Л. 4 об.

${ }^{69}$ Там же. Л. 5.

70 Там же. Л. 5 об.

71 Там же. Л. 61 об.

72 Там же. Л. 28.

73 Там же. Л. 28 об.

74 Там же. Л. 29.
} 
Кроме того, Карташёв предложил заинтересовать вопросами сношений с инославными представителей других соборных Отделов и создать группу, которая будет не только разрабатывать церковно-законодательные вопросы взаимодействия с англиканами и старокатоликами, но и вступать с ними в прямой диалог. Отдел принял за основу своей работы эти идеи, а также просил Карташёва развить их в особом докладе, но тот отказался ${ }^{75}$.

Пятое, проходившее 22 августа (у Шульца неверно 23 августа [там же, S. 91]) (5 сентября) 1918 г. заседание было посвящено ознакомлению соборян с англиканским вероучением по книге профессора Керенского «Американская епископальная церковь», вышедшей в 1908 г. В конце заседания автор книги заявил, что «епископальная Церковь Америки ближе к нам, чем англиканская» 76.

На шестом заседании Отдела 31 августа (12 сентября; у Шульца неверно 13 сентября [там же, S. 93]) был заслушан доклад профессора Керенского о старокатоличестве. Архиепископ Евдоким поделился личными впечатлениями от общения с мариавитами - одним из направлений старокатоличества ${ }^{77}$. Неожиданно прозвучал поддержанный епископом Симоном призыв Карташёва к объединению с инославными конфессиями на новых началах: «Теперь необходимо образовать крупное единение, не уклоняясь даже от молитвенного общения с инославными. И только пробудивши в сердцах иноверцев дружбу и любовь к себе, можем надеяться на установление и богословского единения с ними» ${ }^{78}$. Очевидно, что начавшиеся гонения заставляли лучшие церковные умы искать поддержки у инославных, даже пренебрегая каноническим запретом на совместную молитву.

Последним стало седьмое заседание, на котором обсуждали вопрос о различиях старокатолического учения от православного. На нём Отдел выработал финальную формулу для принятия Собором ${ }^{79}$. Г. Шульц обратил внимание, что на последнем заседании Отдела присутствовало всего семь членов (в протоколе и листе присутствия указаны восемь членов, включая председателя), но результаты работы Отдела были переданы в общее собрание Собора. Протокол не доносит до нас сведений о том, успел ли прозвучать на заседании доклад профессора Соколова «по вопросу о соединении Православной Церкви с р[имско]католическою» ${ }^{80}$.

19 сентября 1918 г. Соборный Совет заслушал доклад Отдела о единении с Православной Церковью всех христианских исповеданий, после чего включил рассмотрение этого проекта в повестку дня последнего пленарного заседания Собора.

\footnotetext{
75 Там же. Л. 31.

76 Там же. Л. 50.

77 Там же. Л. 56-56 об.

78 Там же. Л. 57.

79 Там же. Л. 7-7 об.

${ }^{80}$ Там же. Л. 72.
} 
Общему собранию было предложено принять постановление из двух пунктов, первым из которых Собор благословлял труды «работающих над изысканием пути к единению с названными дружественными церквами (старокатоликами и англиканами - A.M.)». Во втором пункте содержалась рекомендация Св. Синоду создать в своей структуре постоянно действующую комиссию для диалога с указанными христианскими конфессиями ${ }^{81}$. На последнем, 170-м заседании Собор принял постановление без изменений. Решения Поместного Сoбора подлежали утверждению Совещанием епископов, но на последнем совещании 22 сентября 1918 г. решение 170-го заседания Собора не рассматривалось. По этой причине принятое Собором «постановление относительно соединения Церквей» не вошло в официальное «Собрание определений и постановлений Священного Собора Православной Российской Церкви 1917-1918 годов» ${ }^{82}$

Задуманная на роль преемницы Комиссии по старокатолическому и англиканскому вопросам Комиссия в совершенно новых условиях и с другими целями была создана в 1946 г. - как Отдел внешних церковных сношений Московской Патриархии (ныне Отдел внешних церковных связей).

Вопрос о единении с инославными христианами поднимался не только на Соборе. В конце августа 1918 г ${ }^{83}$ к патриарху обратилось действовавшее с 1912 г. «Общество ревнителей сближения Англиканской церкви с Православною», членом которого был и сам адресат. Авторы письма подчёркивали, что в дни «ужаснейшей мировой войны» верующие сильнее скорбят «по христианскому братству, по христианской любви, по единству всего христианского мира» ${ }^{84}$. Война сильно мешает «правильности сношений нашего русского общества с однородным английским», но не в силах «уничтожить установившиеся чувства взаимного расположения и любви и стремления к дальнейшему сближению» ${ }^{85}$. Авторы предлагали внести в полный православный месяцеслов около 300 имён английских святых, живших до разделения Церкви, и разрешить членам общества раз в год совершать одну из древних английских литургий ${ }^{86}$. Обращение подписали члены Собора во главе с митрополитом Петроградским Вениамином (Казанским) и члены «Англиканского общества», не бывшие соборянами, в том числе такие известные, как протоиерей Философ Орнатский, граф Н.Ф. Гейден и священник Карп Эльб.

Любопытно отложившееся в архиве Собора заказное письмо с обращением к товарищу секретаря Собора профессору В.Н. Бенешевичу автора широ-

\footnotetext{
${ }^{81}$ Там же. Д. 494. Л. 41.

82 Вопрос о соединении Церквей на Поместном Соборе // Православие и экуменизм. Документы и материалы 1902-1998. М., 1999. С. 67.

83 Указываем по старому стилю, по новому стилю не позднее 13 сентября, которым Г. Шульц некорректно датирует это письмо [17, S. 73]. Это дата получения письма соборной канцелярией и его рассмотрения Тихоном, письмо авторами не датировано.

${ }^{84}$ ГАРФ. Ф. 3431. Оп. 1. Д. 495. Л. 8.

85 Там же. Л. 8 об.-9.

${ }^{86}$ Там же. Л. 9-10.
} 
ко известной до революции кулинарной книги «Подарок молодым хозяйкам» Е.И. Молоховец. 87-летняя дама просила своего адресата, с которым не была знакома лично, приехать к ней в Петроград на беседу «с разрешения Его Святейшества Патриарха Тихона, до сведения которого я бы хотела, чтобы дошла весть о моей начатой деятельности (по воссоединению западных христиан с Православной Церковью - A.M.)» ${ }^{87} .17$ (30) августа 1918 г. Бенешевич отправил ей ответ, уведомив о невозможности выехать в Петроград и сообщив о создании Отдела по единению церквей. В письме содержалась просьба выслать Собору имевшийся у неё материал по взаимодействию с англиканами и католиками ${ }^{88}$. Неизвестно, успела ли Молоховец отправить эти материалы, в соборном архиве их нет. Именитая просительница скончалась в декабре того же года.

Свои предложения по христианскому единству представил музыковед Bc.Е. Чешихин, считавший, что «в ближайшем будущем достаточно хлопотать о соединении христианских церквей, для чего следовало бы учредить "Всероссийский союз христианских соииалистов", одною из задач которого была бы подготовка и созыв Вселенского Собора христианских исповеданий» ${ }^{89}$. В связи с тем, что это предложение, поступившее в Отдел о соединении церквей, обстоятельно проанализировал Г. Шульц [там же, S. 96-97], нет необходимости на нём останавливаться.

Энтузиасты воссоединения с Православной Церковью наиболее близких по духу и учению инославных конфессий проделали немалую работу в дореволюционные десятилетия. Собор мог стать если не апофеозом, то немаловажным переходным этапом этой деятельности. Предстояла серьёзная работа в этом направлении, которая была прервана с лишением Русской Церкви всякой самостоятельности.

\section{Зарубежная пресса}

Канцелярия Собора 26 января 1918 г. выдала аккредитацию корреспонденту французской газеты «Фигаро» Рене Маршану ${ }^{90}$ (подробнее о нём [2]). Это французское издание следило за событиями в церковно-государственных отношениях России 91 , но специальные материалы о Соборе не публиковались, так что аккредитацию можно считать номинальной. Публикация новостей о Соборе и его деяниях в газетах других стран требует специального исследования, однако очевидно, что в них могли появляться только вторичные материалы.

\footnotetext{
${ }^{87}$ Там же. Л. $73-73$ об.

88 Там же. Л. 74.

${ }^{89}$ Призыв (Петроград). 1918. № 12 (3 сентября). С. 4. Цит. по: ГАРФ. Ф. 3431. Оп. 1. Д. 495. Л. 95.

90 ГАРФ. Ф. 3431. Оп. 1. Д. 502. Л. 21.

${ }^{91}$ Например, в выпуске от 14 февраля 1918 г. сообщалось о декрете об отделении Церкви от государства, о протестах против него и о визите патриарха Тихона в Петроград. Le Figaro. 1918. 14 fevrier. P. 2.
} 


\section{Выводы}

В трудных условиях великий московский Собор в 1917 г. смог объединить представителей российских церковно-административных установлений, приехавших из-за рубежа служителей Русской Церкви и делегатов других православных Церквей. На короткое время Собор стал центром диалога русского православия с инославным христианством. С определённой натяжкой деятельность Собора можно назвать протоэкуменической.

Продолжая в вопросах диалога с православными дореволюционную линию, в новых условиях Церковь намеревалась создать для этой работы официальные структуры, а не вести диалог с помощью общественных организаций как в дореволюционный период. Активизировался процесс работы миссий за рубежом, вскоре прерванный из-за лишения Церкви финансовой самостоятельности.

За время проведения Собора международные вопросы перешли в повестке дня из разряда периферийных в значимые.

Решения и идеи Собора после его завершения приобрели новую актуальность в зарубежных пределах. Иностранные делегаты высказались за восстановление патриаршества, в целом, они стали реципиентами соборных решений и соборного духа.

Рассмотренные свидетельства и документы дают основание утверждать, что Собор отвечал требованиям времени, а в части межконфессиональных связей даже опережал их.

Собор сформировал отправную точку новой системы международного восприятия и международных связей Русской Церкви. Миссия, финансируемая не государством, но Церковью, могла стать реальностью. То обстоятельство, что соборная модель не реализовалась на практике, никак не умаляет значения Собора в сфере конструирования международных и межцерковных связей.

\section{Приложение. Инициаторы создания и участники заседаний Отдела о соеди- нении церквей}

Addendum. The initiators of the creation and the participants of the meetings of the Department churches reunification

\begin{tabular}{|l|c|c|c|c|c|c|c|}
\hline Инициаторы создания и участники заседаний & 3апись в Отдел & \multicolumn{5}{|c|}{ Номера заседаний Отдела } \\
\hline & & $\mathbf{2}$ & $\mathbf{3}$ & $\mathbf{4}$ & $\mathbf{5}$ & $\mathbf{6}$ & $\mathbf{7}$ \\
\hline Аксенов Леонид Дмитриевич & + & & & + & + & & \\
\hline Александр (Григорьев), архимандрит & + & + & + & + & & & \\
\hline Анатолий (Грисюк), епископ & & + & & + & & & \\
\hline Артамонов Леонид Константинович & + & + & & & & + & + \\
\hline Афанасий (Сахаров), иеромонах & + & + & & + & + & + & \\
\hline Бахметьев Василий Яковлевич & + & & & & & & \\
\hline Боголюбов Феодор Семенович & + & & & & & & \\
\hline Боярчук Григорий Иванович & + & & & & & & \\
\hline
\end{tabular}




\begin{tabular}{|c|c|c|c|c|c|c|c|}
\hline \multirow[t]{2}{*}{ Инициаторы создания и участники заседаний } & \multirow[t]{2}{*}{ Запись в Отдел } & \multicolumn{6}{|c|}{ Номера заседаний Отдела } \\
\hline & & 2 & 3 & 4 & 5 & 6 & 7 \\
\hline Бриллиантов Александр Иванович & + & + & + & & + & + & + \\
\hline Васильев Афанасий Васильевич & + & + & & & + & & + \\
\hline Витошинский Емилиан Михайлович & + & + & & + & & & + \\
\hline Владимир, архимандрит & + & & & & & & \\
\hline Глаголев Сергей Сергеевич & + & & & & + & + & \\
\hline Говоров Николай Георгиевич & + & + & & & & & \\
\hline Громогласов Илья Михайлович & + & & & & & & \\
\hline Демидов Валерий Аркадьевич & + & & + & & + & & \\
\hline Дроздов Иоанн Никандрович, протоиерей & & + & & & & & \\
\hline Евдоким (Мещерский), архиепископ & & + & + & + & + & + & + \\
\hline Жукович Платон Николаевич & + & + & & & & & \\
\hline Зайц Кирилл Иоаннович, протоиерей & + & & & & & & \\
\hline Зеленцов Василий Иванович & + & & & & & & \\
\hline Иларион (Троицкий), архимандрит & & & & + & & & \\
\hline Июдин Александр Иванович & & + & & & + & & \\
\hline Карташев Антон Владимирович & + & & & + & & + & \\
\hline Керенский Владимир Александрович & + & + & + & + & + & + & + \\
\hline Котляревский Сергей Андреевич & + & & & & & & \\
\hline Лахостский Павел Николаевич, протоиерей & + & & & & & & \\
\hline Малыгин Николай Григорьевич & + & & & & + & & \\
\hline Мансуров Павел Борисович & + & & & & + & & \\
\hline Михаил (Урошевич), архимандрит & + & & & + & & & \\
\hline Недельский Владимир Климентович & + & + & + & & + & & \\
\hline Никодим (Кротков), епископ & + & & & & & & \\
\hline Олсуфьев Димитрий Адамович & + & & & & & & \\
\hline Ольховский Григорий Александрович & + & & & & & & \\
\hline Овсянников Алексей Николаевич & & + & & & & & \\
\hline Остроумов Михаил Андреевич & & + & + & + & + & & \\
\hline Павел (Вильковский), епископ & & + & & & & & \\
\hline Попов Александр Александрович, священник & + & + & + & & & & \\
\hline Преображенский Николай Александрович & & + & & & & & \\
\hline $\begin{array}{l}\text { Преображенский Алексей Феоктистович, } \\
\text { протоиерей }\end{array}$ & + & & & & & & \\
\hline Пулга Павел Владимирович & + & + & & + & & & \\
\hline Россейкин Феодор Михайлович & + & + & + & + & + & + & \\
\hline Сапин Роман Емельянович & & + & + & & & & \\
\hline Серафим (Александров), епископ & + & & & & & & \\
\hline Симон (Шлеев), епископ & & + & & & + & + & \\
\hline Синцов Василий Иванович, протоиерей & + & + & & & & & \\
\hline Сироткин Николай Михайлович, священник & + & & & & & & \\
\hline Соколов Иван Павлович & + & + & + & + & & + & + \\
\hline
\end{tabular}




\begin{tabular}{|c|c|c|c|c|c|c|c|}
\hline \multirow[t]{2}{*}{ Инициаторы создания и участники заседаний } & \multirow[t]{2}{*}{ Запись в Отдел } & \multicolumn{6}{|c|}{ Номера заседаний Отдела } \\
\hline & & 2 & 3 & 4 & 5 & 6 & 7 \\
\hline $\begin{array}{l}\text { Стальмашевский Александр Михайлович, } \\
\text { священник }\end{array}$ & & & + & & + & & \\
\hline Теодорович Терентий Павлович, протоиерей & & + & + & & & & \\
\hline Титлинов Борис Васильевич & + & & & & & & \\
\hline Тихон (Оболенский), епископ & + & & & & & & \\
\hline Тураев Борис Александрович & & & & & + & & \\
\hline Филоненко Феодор Димитриевич, протоиерей & + & + & + & & + & + & + \\
\hline Фиолетов Николай Николаевич & + & & & & & & \\
\hline $\begin{array}{l}\text { Хотовицкий Александр Александрович, } \\
\text { протоиерей }\end{array}$ & + & & & + & & & \\
\hline Черноуцан Александр Миныч & & & & & + & & \\
\hline Юницкий Александр Иоаннович, протоиерей & + & & & & + & + & \\
\hline
\end{tabular}

Источник: составлена по тистам записи в Отдел и подписным тистам заседаний Отдела (отложились в деле: ГАРФ. Ф. 3431. Оп. 1. Д. 495), при участии специалиста по расшифровке подписей членов Собора 1917-1918 г2. историка и теолога священника Евгения Агеева, которому автор выражает благодарность за эту помощь.

\section{Список литературы:}

1. Бесстремянная Г.Е. Контакты Русской духовной миссии в Корее и Японской Православной Церкви в 1896-1946 годы // Церковь и время. 2009 № 2 (47). С. 113-215.

2. Галкина Ю.М. Французский журналист Рене Маршан: несколько штрихов к портрету «друга советской России» // Вестник РУДН. Серия «История России». 2019. Т. 18. № 1. С. 85-100.

3. Дестивель Иакинф, священник. Поместный Собор Российской Православной Церкви 1917-1918 гг. и принцип соборности. М., 2008. $307 \mathrm{c}$.

4. Документы Священного Собора Православной Российской Церкви 1917-1918 годов. Т. 1. Предсоборная работа 1917 года. Акты, определявшие порядок созыва и проведения Собора. М., 2012. 1376 c.

5. Документы Священного Собора Православной Российской Церкви 1917-1918 годов. Т. 5. Деяния Собора с 1-го по 36-е / отв. ред. священник Алексий Колчерин, А.И. Мраморнов. М., 2015. 938 c.

6. Конь Р.М. Браки с инославными и сектантами в России по документам подготовки Поместного Собора 1917-1918 годов // Богословский вестник. 2017. № 24-25. Вып. 1-2. С. 305-348.

7. Косик В.И., Шестаков А.В. Варнава (Росич Пе- тар), митр. Белградско-Карловацкий и Патриарх Сербский // Православная энциклопедия. М., 2003. Т. 6. С. 648-649.

8. Кравецкий А.Г. Церковная миссия в эпоху перемен (между проповедью и диалогом). М., 2012. $712 \mathrm{c}$.

9. Лепилин А.В. Взаимодействие Русской Православной Церкви с экуменическим движением в период его зарождения и развития (1917-1961). Автореферат дис. ... кандидата исторических наук. Орёл, 2004.

10. Суханова Н.А. История Японской Православной Церкви в XX веке: путь к автономии. СПб., 2013. 418 с.

11. Торопов Д.А. Первый этап переговоров представителей Российской Православной Церкви со старокатоликами (1871-1875 гг.) // Церковно-исторический вестник. М., 2009-2010. № 16-17. С. 47-54.

12. Торопов Д.А. Командировки представителей Российской Православной Церкви на старокатолические конференции и конгрессы (1871-1913) // Церковь и время. 2014. № 4 (69). C. 188-206.

13. Федотов С.П., Новиков В.Ф., Меркулов А.В. Политические факторы и последствия московской встречи православных и англикан 
в 1943 году // Среднерусский вестник общественных наук. 2018. Том 13. № 4. С. 118-133.

14. Шевченко Т.И. Поместный Собор Православной Российской Церкви 1917-1918 гг. о положении православных в Финляндии // Вестник ПСТГУ. История. История Русской Православной Церкви. 2011. № 6 (43). С. 85-116.

15. Dunn, Dennis J. The Catholic Church and Soviet Russia, 1917-1939. London - New York, 2017. $142 \mathrm{p}$.
16. Fitzgerald, Thomas E. The ecumenical movement: an introductory history. Westport, 2004. 276 p.

17. Schulz, Günter. Das Landeskonzil der Orthodoxen Kirche in Rußland - ein unbekanntes Reformpotential. Göttingen, 1995. 212 S.

18. Schulz, Günter. Der Ausschuß für die Vereinigung der Kirchen des Landeskonzils der Orthodoxen Kirche in Rußland 3./16.8. bis 7./20.9.1918 // Kirche im Osten. 1996. Bd. 39. S. 70-100.

\title{
06 авmope:
}

Александр Игоревич Мраморнов - к.и.Н., доцент, руководитель Некоммерческого партнёрства по защите и сохранению объектов культурного наследия «Спасское дело». 442823, Пензенская область, Колышлейский район, с. Старая Потловка, ул. Светлая, д. 1, mramornov@gmail.com.

\section{Issues of International and Interchurch Relations in the Work of Holy Council 1917-1918 of the Orthodox Russian Church}

\author{
A.I. Mramornov \\ DOI 10.24833/2071-8160-2019-3-66-176-201
}

Non-profit partnership «Spasskoe delo»

\begin{abstract}
The convocation of the Local Council in 1917, the first Council in over two centuries, had a great significance for the internal life of the Orthodox Church of Russia. But in a period when the World War was still ongoing and there were pressing issues to resolve in the sphere of cooperation of Russian Orthodoxy with other orthodox and non-orthodox churches, the Local Council could not but touch upon the international and inter-church issues. For the first time in the history of Russian Church the official ecclesiastical forum was attended by official elected delegates who served abroad and who could bring the opinion of the foreign part of the Russian Church to its «maternal» part and to provide the mutually beneficial exchange of practices and opinions.

Moreover, in a situation when the church was liberated from the tutelage of the state, it became possible to engage with foreign religious organizations not through social organizations or the Ministry of Foreign Affairs, but directly. This opened a way for creating the Church's own structures which would be responsible for contacts with other confessions, including Old-Catholics and Anglicans, with whom there had already been lengthy unofficial dialogue.

The efforts of some historians and publicists shaping contemporary discourse in Russia depict the restoration of the Patriarchate in the Russian Church as the only important act of the Council are challenged by the material presented in this article, which shows how the Council constructed the future position of Russian Orthodoxy in dialogue with the non-
\end{abstract}


Orthodox churches, in its presence abroad and its missions in non-Christian countries. The word of the Council in this sphere was completely new and never before told. The Council was ahead of its time in the issues of international connections (like in many other spheres of its work). Many issues at the Council were expressed for the first time or in a completely new way. How to manage the missions abroad (in Japan, China, Korea, Urmia, and Palestine)? The Council, occupied with the internal problems in the situation of the beginning of persecution against it, could not abandon these missions. How was it possible to unite Russian emigrants abroad? The idea of Paris as a centre of their unification was expressed for the first time at the Council.

The scholars who touched upon these issues before analyzed them through the concept of ecumenism (following the participation of the Russian Church in the ecumenical movement). But it seems more appropriate to research them in the context of the time of the Council itself, since it was a time that preceded the emergence of the Ecumenical Movement proper.

The author of the article draws a conclusion that during the year of the Council (August 1917 - September 1918) the issues of international and inter-church relationships transformed in its agenda from being of secondary to primary importance. This conclusion allows us to challenge the dismissive perspective that the Moscow Council 1917-1918 was ineffective. Although it did not have time to complete its agenda, the Council was ahead of its time and contributed much for the future mission of the Russian Church in the modern world.

Key words: Russian Orthodox Church, Local Council, Anglicans, old-catholic movement, Tikhon (Bellavin), Evdokim (Mescherskiy), A.V. Kartashev, I. P. Sokolov, I. I. Sokolov, ecumenism, Christian unity.

\section{References}

1. Besstremjannaja G. E. Kontakty Russkoj duhovnoj missii v Koree i Japonskoj Pravoslavnoj Cerkvi v 1896-1946 gody [Contacts between Russian spiritual mission in Korea and Japanese Orthodox Church in 1896-1946]. Cerkov' i vremja [Church and time]. 2009, no. 2 (47), pp. 113-215. (In Rus-sian).

2. Galkina Ju. M. Francuzskij zhurnalist Rene Marshan: neskol'ko shtrihov k portretu «druga sovetskoj Rossii» [French journalist René Marchand: a few strokes to the portrait of "a friend of Soviet Russia”]. Vestnik RUDN. Serija «Istorija Rossii». 2019, vol. 18, no. 1, pp. 85-100. (In Russian)

3. Destivel' Iakinf, svjashhennik. Pomestnyj Sobor Rossijskoj Pravoslavnoj Cerkvi 1917-1918 gg. i princip sobornosti [Destivelle Hyacinthe, priest. The Local Council of the Russian Orthodox Church of 1917-1918 and the principle of conciliarity]. Moscow, 2008. 307 p. (In Russian)

4. Dokumenty Svjashhennogo Sobora Pravoslavnoj Rossijskoj Cerkvi 1917-1918 go- dov. T. 1. Predsobornaja rabota 1917 goda. Akty, opredeljavshie porjadok sozyva i provedenija Sobora [Documents of the Holy Council of the Orthodox Russian Church in 1917-1918. Volume 1. Preconciliar work of 1917. Acts that regulated the procedure of convening and the work of the Council]. Moscow, 2012. 1376 p. (In Russian)

5. Dokumenty Svjashhennogo Sobora Pravoslavnoj Rossijskoj Cerkvi 1917-1918 godov. T. 5. Dejanija Sobora s 1-go po 36-e / otv. red. svjashhennik Aleksij Kolcherin, A.I. Mramornov. [Documents of the Holy Council of the Orthodox Russian Church, 1917-1918. Volume 5. The Acts (stenograms) of the Council from the 1st to the $36^{\text {th }}$. Edited by priest Alexei Kolcherin and A.I. Mramornov]. Moscow, 2015. 938 p. (In Russian).

6. Kon' R.M. Braki s inoslavnymi i sektantami v Rossii po dokumentam podgotovki Pomestnogo Sobora 1917-1918 godov [Marriages with non-Orthodox and sectarians in Russia according to the docu- 
ments of preparation of the Local Council of 1917-1918]. Bogoslovskij vestnik. 2017, no, 24-25, issue 1-2, pp. 305-348. (In Russian).

7. Kosik V. I., Shestakov A. V. Varnava (Rosich Petar), mitr. Belgradsko-Karlovackij i Patriarh Serbskij [Varnava (Rosic Petar), metropolitan of Belgrad-Karlovci]. Pravoslavnaja jenciklopedija. Moscow, 2003, vol. 6, pp. 648-649. (In Russian)

8. Kraveckij A. G. Cerkovnaja missija v epohu peremen (mezhdu propoved'ju $i$ dialogom) [Church mission in the times of changes (among preaching and dialogue)]. Moscow, 2012. 712 p. (In Russian)

9. Lepilin A. V. Vzaimodejstvie Russkoj Pravoslavnoj Cerkvi s jekumenicheskim dvizheniem $v$ period ego zarozhdenija $i$ razvitija (1917-1961). Avtoreferat dissertatsii ... kandidata istoricheskih nauk. [The cooperation of the Russian Orthodox Church with the ecumenical movement in the period of its birth and development (1917-1961). Essay of the dissertation of the candidate of historical sciences] Orel, 2004. (In Russian)

10. Suhanova N. A. Istorija Japonskoj Pravoslavnoj Cerkvi v XX veke: put' $k$ avtonomii. [History of the Japanese Orthodox Church in the 20th century: the way to autonomy]. Saint Petersburg, 2013. 418 p. (In Russian)

11. Toropov D.A. Pervyj etap peregovorov predstavitelej Rossijskoj Pravoslavnoj Cerkvi so starokatolikami (1871-1875 gg.). [The first period of the negotiations between the representatives of the Russian Orthodox Church and the Old Catholic movement (1871-1875)]. Cerkovno-istoricheskij vestnik. Moscow, 2009-2010, no. 16-17, pp. 47-54. (In Russian).
12. Toropov D.A. Komandirovki predstavitelej Rossijskoj Pravoslavnoj Cerkvi na starokatolicheskie konferencii i kongressy (1871-1913) [Visits of representatives of the Russian Orthodox Church to Old Catholic conferences and congresses (1871-1913)]. Cerkov' i vremja. 2014, no. 4 (69), pp. 188-206. (In Russian).

13. Fedotov S.P., Novikov V.F., Merkulov A.V. Politicheskie faktory i posledstvija moskovskoj vstrechi pravoslavnyh i anglikan v 1943 godu [Political factors and consequences of the Moscow meeting of Orthodox and Anglicans in 1946]. Srednerusskij vestnik obshhestvennyh nauk. 2018, vol. 13, no 4, pp. 118-133. (In Russian).

14. Shevchenko T.I. Pomestnyj Sobor Pravoslavnoj Rossijskoj Cerkvi 1917-1918 gg. o polozhenii pravoslavnyh v Finlyandii [The Local Council of the Russian Church 1917-1918 about the status of the orthodox people in Finland]. Vestnik PSTGU. Istoriya. Istoriya Russkoj Pravoslavnoj Cerkvi. 2011, no. 6 (43), pp. 85-116. (In Russian).

15. Dunn D. J. The Catholic Church and Soviet Russia, 1917-1939. London - New York, 2017. 142 p.

16. Fitzgerald Th. E. The ecumenical movement: an introductory history. Westport, 2004. 276 p.

17. Schulz G. Das Landeskonzil der Orthodoxen Kirche in Rußland - ein unbekanntes Reformpotential. Göttingen, 1995. 212 S. (In German).

18. Schulz G. Der Ausschuß für die Vereinigung der Kirchen des Landeskonzils der Orthodoxen Kirche in Rußland 3./16.8. bis 7./20.9.1918. Kirche im Osten. 1996, Bd. 39, S. 70-100. (In German)

\section{About the author:}

Alexander I. Mramornov — head of the Non-profit partnership «Spasskoe delo», candidate of historical sciences, associate professor. Svetlaya str. 1, Staraya Potlovka village, Kolyshleyskiy district, Penza oblast, 442823, Russia. E-mail: mramornov@gmail.com. 